\title{
Phytoplankton community structure in the Estuary of Donan River, Cilacap, Central Java, Indonesia
}

\author{
HESTI PRATIWI, ARIO DAMAR, SULISTIONO ${ }^{\vee}$ \\ Department of Aquatic Resources Management, Faculty of Fisheries and Marine Science, Institut Pertanian Bogor. Jl. Raya Darmaga, Bogor 16680, \\ West Java, Indonesia. Tel./fax.: +62-251-8623644, ’email: onosulistiono@gmail.com
}

Manuscript received: 30 October 2017. Revision accepted: 26 October 2018.

\begin{abstract}
Pratiwi H, Damar A, Sulistiono. 2018. Phytoplankton community structure in the Estuary of Donan River, Cilacap, Central Java, Indonesia. Biodiversitas 19: 2104-2110. The estuary of the Donan River in Cilacap, Central Java is one of the areas utilized for many activities, including industries, housings, port facilities, tourism, and fisheries. This study was aimed to determine the aquatic condition of the estuary based on phytoplankton indicator. Samples were taken at 5 stations, representing salinity distribution at the river mouth from August 2015 to January 2016. Data were analyzed and presented as the abundance, composition, and Diversity, Evenness, Dominance, and Bray-Curtis Similarity Indexes of phytoplankton. Principal Component Analysis was used to analyze the effect of environmental parameters on phytoplankton diversity and abundance. The results showed that phytoplankton at the estuary comprised of three classes, i.e., Bacillariophyceae (17 genera), Chlorophyceae (4 genera), and Dinophyceae (1 genus). The phytoplankton diversity at the estuary was classified as moderately ecological stressed. Phytoplankton species distribution appeared similar across sampling time and station. Habitat cluster based on the phytoplankton abundance was classified into 3 zones namely Zone 1 (Donan), Zone 2 (Teluk Penyu), and Zone 3 (Kembangkuning). Nitrate, temperature, salinity, dissolved oxygen (DO), transparency, and orthophosphate were aquatic parameters affecting the phytoplankton community structure at this estuary.
\end{abstract}

Keywords: Community structure, phytoplankton, Donan Estuary, Indonesia.

\section{INTRODUCTION}

The Segara Anakan is a lagoon located in the south part of Cilacap Regency, Central Java, Indonesia. This lagoon is protected from the wave action from the Indian Ocean by the existence of Nusakambangan Island. The island is situated in front of the Segara Anakan stretching 30 kilometers from east to west. The ecosystem in the Segara Anakan is very important both ecologically and economically due to its high biodiversity and rich of nutrient. The habitat of the coastal area in the Segara Anakan had been degraded over the last few decades due to the rapid human population growth and land use, causing destruction of mangroves and severe sedimentation in the lagoon (Ardli 2008).

Fisheries resources in the Segara Anakan had been threatened by habitat destruction and pollution from industrial as well as household wastes. One of the water bodies in the Segara Anakan Lagoon which was subject to the degradation was the estuary of Donan River. This lagoon is situated close to the industrial areas, seaports, and domestic areas. According to Cahyani (2001), the oil processing industry was located in the east part of the Donan River, and its activity might lead to the contamination to the Donan River.

The waste found in this estuary was originated from the industry and domestic activities in Cilacap. Partuti (2014) reported that oil and gas industries were potential to pollute the water. Robinson (2010) further reported that the wastewater released contained oil residual dispersed in the form of droplets, solids, gases, and soluble hydrocarbons in small quantities. Plankton is one of aquatic organisms utilized as bio-indicator of aquatic condition. The turbidity is considered as one of the important factors which can affect the distribution and abundance of phytoplankton (Gao and Song, 2005).

The aim of this study was to determine the aquatic condition based on the phytoplankton community structure in the estuary of the Donan River, Cilacap, Central Java, Indonesia.

\section{MATERIALS AND METHODS}

\section{Study area}

The study area was in the estuary of the Donan River, Cilacap, Central Java, Indonesia (Figure 1). Phytoplankton sampling and environmental parameters measuring were conducted every month from August 2015 to January 2016.

\section{Procedures \\ The phytoplankton sampling and identification}

Phytoplankton samples were taken at each station by filtering 100 liters water using a plankton net in each sampling station. The filtered samples were then kept in sample bottles preserved with Lugol's solution. All samples were kept cool prior to analysis by keeping them in a cool box and brought to the main lab for laboratory analyses. 


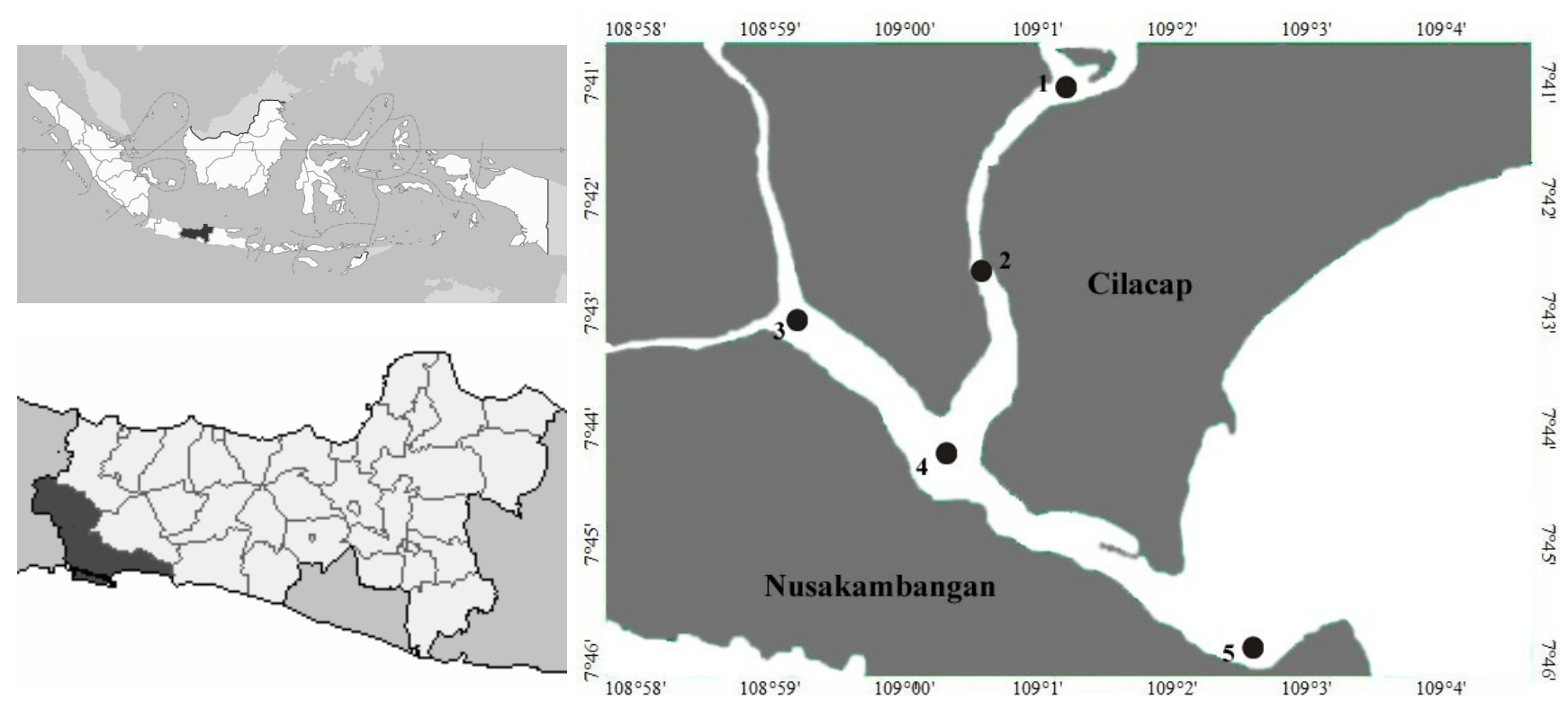

Figure 1. The study sites in the estuary of the Donan River, Cilacap, Central Java, Indonesia

Table 1. Method of physical-chemical parameters measurement observed (APHA 2012)

\begin{tabular}{|c|c|c|c|}
\hline Parameter & Unit & $\begin{array}{l}\text { Method/measuring } \\
\text { instrument }\end{array}$ & Notes \\
\hline \multicolumn{4}{|l|}{ Physical } \\
\hline Water depth & $\mathrm{m}$ & Weighted Rope & In-situ \\
\hline Temperature & ${ }^{\circ} \mathrm{C}$ & SCT meter & In-situ \\
\hline Transparency & $\mathrm{cm}$ & Secchi disk & In-situ \\
\hline TSS & $\mathrm{mg} / \mathrm{L}$ & Gravimetric & Laboratory \\
\hline \multicolumn{4}{|l|}{ Chemical } \\
\hline $\mathrm{pH}$ & - & $\mathrm{pH}$ Meter & In-situ \\
\hline Salinity & $\%$ & SCT meter & In-situ \\
\hline DO & $\mathrm{mg} / \mathrm{L}$ & DO Meter & In-situ \\
\hline Nitrite $\left(\mathrm{NO}_{2}-\mathrm{N}\right)$ & $\mathrm{mg} / \mathrm{L}$ & Spectrophotometer & Laboratory \\
\hline Nitrate $\left(\mathrm{NO}_{3}-\mathrm{N}\right)$ & $\mathrm{mg} / \mathrm{L}$ & Spectrophotometer & Laboratory \\
\hline Ammonia $\left(\mathrm{NH}_{3}-\mathrm{N}\right)$ & $\mathrm{mg} / \mathrm{L}$ & Spectrophotometer & Laboratory \\
\hline $\begin{array}{l}\text { Orthophosphate } \\
\left(\mathrm{PO}_{4}-\mathrm{P}\right)\end{array}$ & $\mathrm{mg} / \mathrm{L}$ & Spectrophotometer & Laboratory \\
\hline
\end{tabular}

Phytoplankton identification was carried out in the laboratory using compound microscope with 100 times magnification. Plankton abundance was counted using a Sedgwick-Rafter Counting Cell (SRC) with $50 \times 20 \times 1 \mathrm{~mm}^{3}$ size.

\section{Measurements of water chemical and physical characteristics}

Water samples were taken from each research station using polyethylene bottle sampler then cooled for preservation. Water depth, temperature, transparency, $\mathrm{pH}$, salinity and dissolved oxygen (DO) were measured in situ. While total dissolved solids (TSS), nitrate, nitrite, ammonia, and orthophosphate were measured in the laboratory. The method of water quality analysis refers to the APHA (2012) presented in Table 1.

\section{Data analysis}

Data on phytoplankton species composition were presented descriptively. Bray Curtis index was used to create zones. Phytoplankton diversity, evenness, similarity, and dominance indexes were calculated using Shannon and Wiener, Bray Curtis and Simpson Dominance Index formula (Odum 1971), respectively.

Principle Component Analysis (PCA) was used to group the phytoplankton based on water chemical and physical properties. The PCA was used to view the information concerning various water quality parameters which correlate with the phytoplankton abundance in the water. The result of the main component analysis was visualized using a biplot chart. The main axis of the biplot chart explains the diversity of the total data.

\section{RESULTS AND DISCUSSION}

\section{Phytoplankton taxon composition}

During the six months of study at five stations, we found three classes of phytoplankton, namely Bacillariophyceae (17 genera), Chlorophyceae (4 genera), and Dinophyceae (1 genus) and Bacillariophyceae was the most abundant plankton in the study area (Table 2, Figures 2-3). In average the abundance of phytoplankton in the estuary of Donan River was highest in December, i.e., $235,52 \times 103 \mathrm{cell} / \mathrm{m}^{3}$.

\section{Diversity, evenness, and dominance indices}

The index value of the highest diversity is obtained in September, while the lowest value is obtained in August. The index value of evenness obtained showed that in September, the index value of evenness was the highest and in August, it was the lowest. The highest index value of dominance obtained was in August, while the lowest one was obtained in September (Table 3, Figure 4). 


\section{Water quality parameter}

The water quality parameters measured in this study including the water depth, transparency, TSS, temperature, $\mathrm{pH}$, salinity, DO, ammonia, ammonium, nitrate, nitrite, and orthophosphate (Table 4). Prior to the water quality data, salinity and TSS seems the main parameters affected the phytoplankton abundance in that estuary.

\section{Grouping stations}

Based on the phytoplankton abundance, each station was grouped based on it's ecological or habitat similarity using the Bray-Curtis index. The results showed that the abundance of phytoplankton had $75 \%$ similarity. Station 1 had the similarity index $88.21 \%$ with Station 2 . Station 3 had similarity index $76.90 \%$ with station 4 . Unlike other stations, Station 5 did not have similarity with other stations (Figure 5).

\section{Relationship between phytoplankton and physicochemical parameters.}

The result of the principal component analysis showed that the phytoplankton of the estuary of the Donan River could be grouped into 3 zones (Figure 6). In zone 1 (Station 1 and 2), the abundance of Chlorophyceae was close to each other and was influenced by water quality, including nitrate, nitrite, TSS, and temperature. In zone 2 (Station 5), the abundance of Bacillariophyceae was partly explained by salinity, transparency, and orthophosphate. In zone 3 (Station 3 and 4), the abundance of Dinophyceae was influenced by ammonium and DO.

The results of the main component analysis were strengthened by correlation test. The correlation test was intended to determine the closeness of the relationship between water quality parameters with phytoplankton abundance. Transparency, temperature, salinity, DO, nitrate, orthophosphate were all positively correlated with phytoplankton abundance (Table 5).

Table 2. Types of phytoplankton found in estuary of Donan River, Cilacap, Indonesia

\begin{tabular}{ll}
\hline Class & Species \\
\hline Bacillariophyceae & Biddulphia sp., Chaetoceros sp., Cocconeis \\
& sp., Coscinodiscus sp., Cyclotella sp., \\
& Denticula sp., Dytilum sp., Eucampia sp., \\
& Gyrosigma sp., Hemialus sp., Hyalodiscus \\
& sp., Melosira sp., Navicula sp., Nitzchia sp., \\
& Pleurosigma sp., Thalassionema sp., \\
& Thalassiotrix sp. \\
Chlorophyceae & Closterium sp., Cosmarium sp., Staurastrum \\
& sp., Volvox $\mathrm{sp}$. \\
Dinophyceae & Pyrocystis $\mathrm{sp}$. \\
\hline
\end{tabular}

Table 5. The correlation of water quality with phytoplankton abundance in the estuary of the Donan River

\begin{tabular}{lc}
\hline Parameters & Phytoplankton \\
\hline Transparency & 0.41 \\
Total Suspended Solid (TSS) & -0.40 \\
Temperature & 0.16 \\
Salinity & 0.74 \\
Dissolved Oxygen (DO) & 0.76 \\
Amonnia & -0.06 \\
Ammonium & -0.06 \\
Nitrate & 0.82 \\
Nitrite & -0.21 \\
Orthophosphate & 0.28 \\
\hline
\end{tabular}

Table 3. The diversity (H'), Evenness index (E), and dominance index (C) of phytoplankton based on sampling time in the estuary of Donan River, Cilacap, Indonesia

\begin{tabular}{lcccccc}
\hline \multirow{2}{*}{ Index } & \multicolumn{7}{c}{ Months } \\
\cline { 2 - 7 } \multicolumn{1}{c}{ Aug (2015) } & Sept & Oct & Nov & Dec & Jan (2016) \\
\hline Diversity Index (H') & $2.04 \pm 0.22$ & $2.32 \pm 0.22$ & $2.31 \pm 0.24$ & $2.18 \pm 0.16$ & $2.27 \pm 0.11$ & $2.16 \pm 0.22$ \\
Evenness Index (E) & $0.82 \pm 0.08$ & $0.88 \pm 0.08$ & $0.87 \pm 0.07$ & $0.81 \pm 0.05$ & $0.85 \pm 0.04$ & $0.83 \pm 0.07$ \\
Dominance Index (d) & $0.18 \pm 0.07$ & $0.13 \pm 0.05$ & $0.13 \pm 0.04$ & $0.16 \pm 0.03$ & $0.14 \pm 0.03$ & $0.15 \pm 0.04$ \\
\hline
\end{tabular}

Table 4. Water physical and chemical parameters of the estuary of Donan River, Cilacap, Indonesia

\begin{tabular}{llcccccc}
\hline \multicolumn{1}{c}{ Parameters } & \multirow{2}{*}{ Unit } & Aug (2015) & Sept & Oct & Nov & Dec & Jan (2016) \\
\hline Physical & & & & & & & \\
Depth & $\mathrm{m}$ & $5.58 \pm 4.06$ & $5.02 \pm 2.86$ & $4.35 \pm 1.78$ & $5.13 \pm 2.99$ & $4.86 \pm 2.58$ & $3.74 \pm 2.22$ \\
Transparency & $\mathrm{cm}$ & $88 \pm 37$ & $86 \pm 34$ & $134 \pm 127$ & $71 \pm 43$ & $79 \pm 18$ & $98 \pm 25$ \\
Total Suspended solid (TSS) & $\mathrm{mg} / \mathrm{L}$ & $18.20 \pm 13.01$ & $9.40 \pm 1.67$ & $13.40 \pm 5.94$ & $.00 \pm 9.72$ & $19.60 \pm 10.81$ & $23.80 \pm 12.07$ \\
Temperature & ${ }^{\circ} \mathrm{C}$ & $27.44 \pm 0.52$ & $27.04 \pm 1.95$ & $28.90 \pm 0.89$ & $28.40 \pm 1.14$ & $30.56 \pm 0.53$ & $31.32 \pm 0.22$ \\
Chemical & & & & & & & \\
pH & & $7.00 \pm 0.00$ & $7.00 \pm 0.00$ & $7.00 \pm 0.00$ & $7.00 \pm 0.00$ & $7.00 \pm 0.00$ & $7.00 \pm 0.00$ \\
Salinity & $\%$ & $33.80 \pm 1.64$ & $31.00 \pm 0.00$ & $35.40 \pm 1.82$ & $29.60 \pm 1.52$ & $26.60 \pm 4.28$ & $27.20 \pm 3.11$ \\
Dissolved Oxygen (DO) & $\mathrm{mg} / \mathrm{L}$ & $7.86 \pm 1.53$ & $7.42 \pm 2.43$ & $8.62 \pm 0.65$ & $8.10 \pm 1.71$ & $7.32 \pm 2.23$ & $8.72 \pm 0.66$ \\
Ammonia (NH3) & $\mathrm{mg} / \mathrm{L}$ & $0.01 \pm 0.01$ & $0.06 \pm 0.04$ & $0.01 \pm 0.00$ & $0.04 \pm 0.03$ & $0.05 \pm 0.04$ & $0.08 \pm 0.06$ \\
Ammonium & $\mathrm{mg} / \mathrm{L}$ & $0.01 \pm 0.01$ & $0.06 \pm 0.04$ & $0.01 \pm 0.00$ & $0.04 \pm 0.03$ & $0.05 \pm 0.04$ & $0.08 \pm 0.06$ \\
Nitrate (NO 3 -N) & $\mathrm{mg} / \mathrm{L}$ & $0.08 \pm 0.03$ & $0.21 \pm 0.26$ & $0.11 \pm 0.04$ & $0.31 \pm 0.11$ & $0.17 \pm 0.09$ & $0.19 \pm 0.08$ \\
Nitrite (NO2-N) & $\mathrm{mg} / \mathrm{L}$ & $0.01 \pm 0.00$ & $0.04 \pm 0.01$ & $0.02 \pm 0.01$ & $0.02 \pm 0.00$ & $0.01 \pm 0.00$ & $0.02 \pm 0.00$ \\
Orthophosphate (PO4-P) & $\mathrm{mg} / \mathrm{L}$ & $0.02 \pm 0.01$ & $0.02 \pm 0.01$ & $0.03 \pm 0.01$ & $0.03 \pm 0.01$ & $0.03 \pm 0.01$ & $0.01 \pm 0.00$ \\
\hline
\end{tabular}




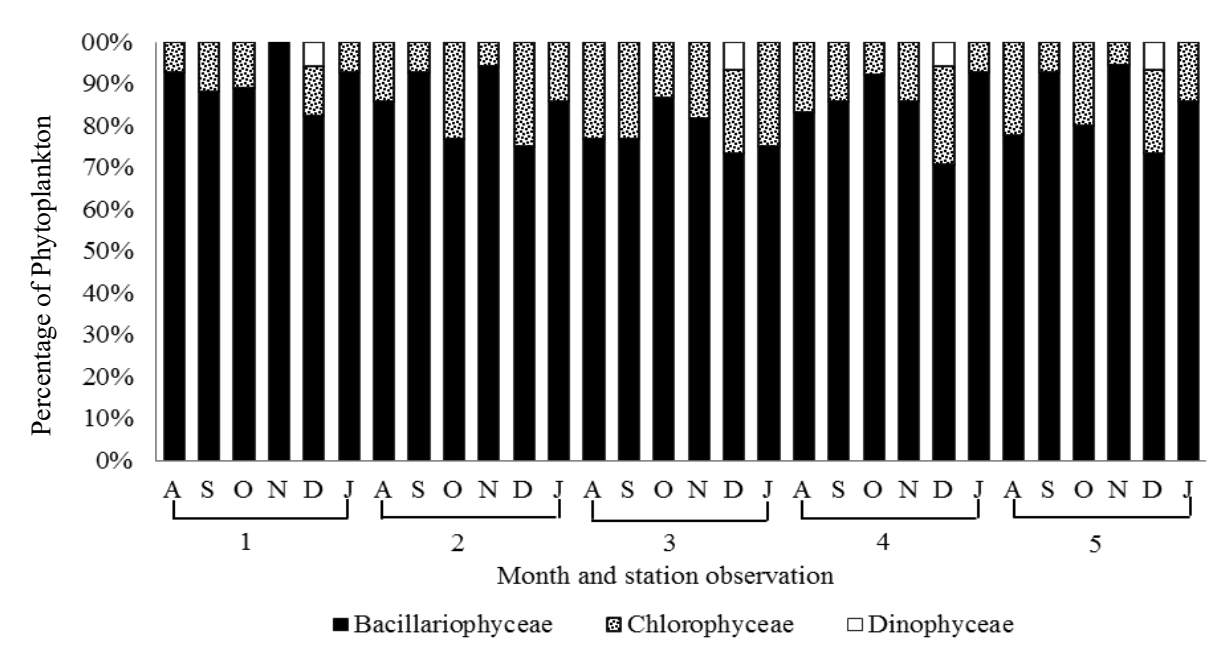

Figure 2. Composition of phytoplankton percentage in the estuary of Donan River, Cilacap, Indonesia, sampled from August 2015 to January 2016

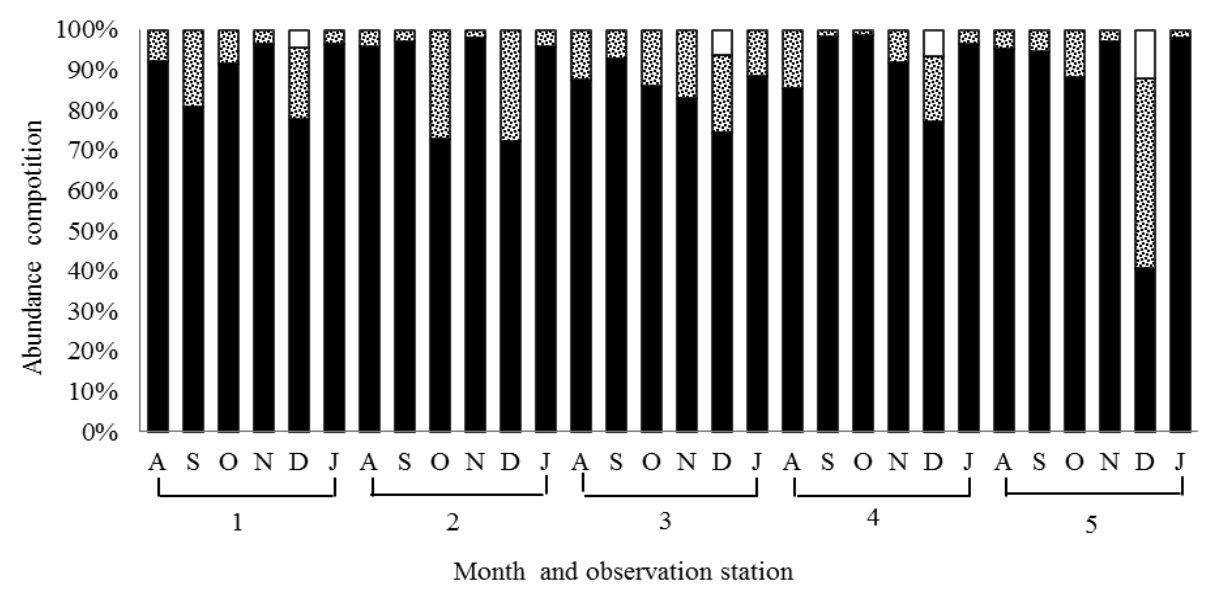

- Bacillariophyceae : Chlorophyceae $\square$ Dinophyceae

Figure 3. Composition of phytoplankton abundance, found in the estuary of Donan River, Cilacap, Indonesia, sampled from August 2015 up to January 2016

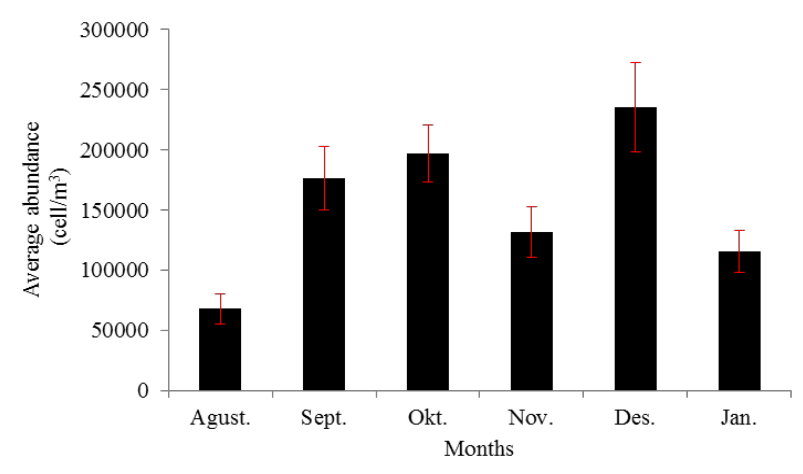

Figure 4. The average abundance of phytoplankton based on the period, in estuary of Donan River, Cilacap, Indonesia

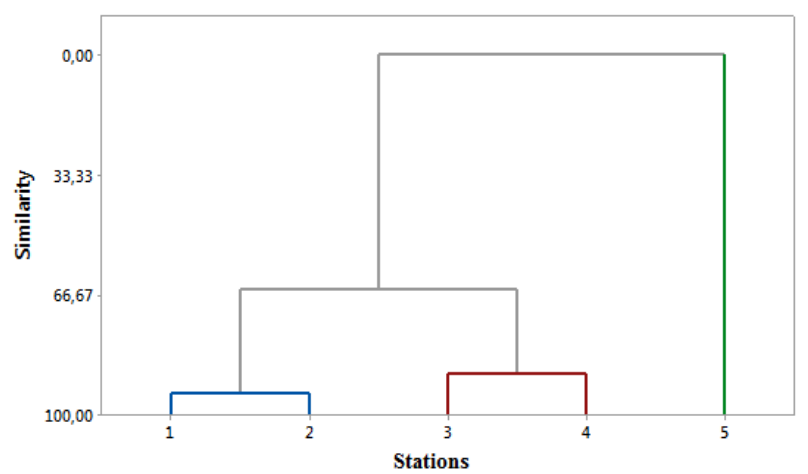

Figure 5. Cluster analysis of stations based on the abundance of the phytoplankton (cell/ $\mathrm{m}^{3}$ ). 


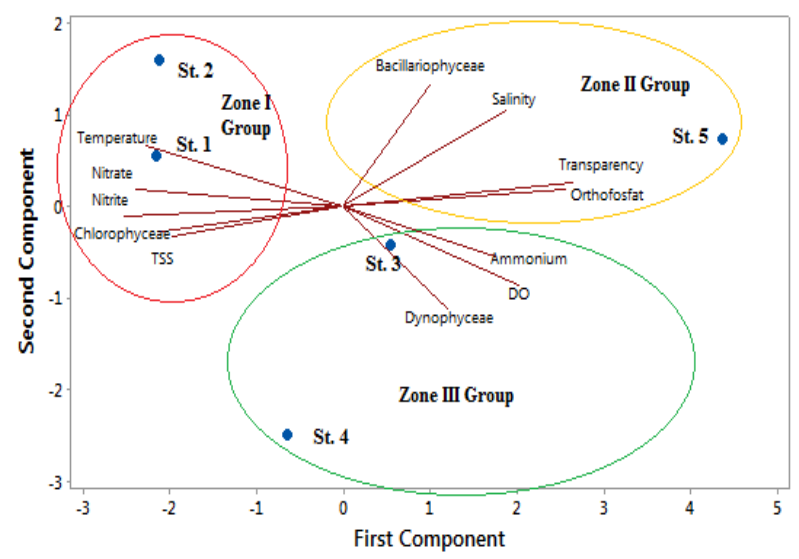

Figure 6. The tendency of water quality with the abundance of phytoplankton $\left(\mathrm{cell} / \mathrm{m}^{3}\right)$ in each zone.

\section{Discussion}

Estuaries form transition zones between freshwater and marine biomes. Due to mixing of the two distinct water bodies, they are characterized by pronounced gradients of physical and chemical components (Bazin et al. 2014). The coastal water gets loads from organic and inorganic substances from land, such as domestic waste from cities brought by the river flowing to the coast. The estuary area of the Donan River has become the center of industrial activity, harbors, transportation, and fisheries (Sudaryanto 2001). If waste dumped into the aquatic environment, it will affect the condition of water quality, which will influence the community of phytoplankton.

The dominance of Bacillariophyceae in coastal water was reported in a number of studies, such as Damar (2003), Brogueira et al. (2007), Isnaini (2011), and Abida (2012). Nastiti et al. (2013) also reported that Bacillariophyceae was a class of phytoplankton commonly abundant in Indonesian waters. Bacillariophyceae was also the most abundant phytoplankton found in the waters of the Alas Strait, Sumbawa (Radiarta, 2013). In Jakarta, Lampung and Semangka Bays, the phytoplankton was also dominated by Bacillariophyceae (Damar et al. 2012). In marine water, Wulandari (2015) and Widyarini (2016) found that this class of phytoplankton was the most common. The dominance of Bacillariophyceae in many studies indicated that Bacillariophyceae as cosmopolitan. This cosmopolitan nature is probably due to Bacillariophyceae can form silent spores which are usually smaller than other Diatom cells and this silent spores can survive and grow well in adverse condition (Basmi,1999; and Siregar, 2006). In addition, these organisms are also euryhaline, which can live in the salinity range of $5 \%$-30 \%.

Chlorophyceae comprised of smaller numbers of genera compared to the genera number in Bacillariophyceae. Chlorophyceae is abundant in waters with sufficient light intensity, such as ponds, and lakes (Ramadhania et al. 2015). Dinophyceae is a class which only occasionally found in a low number of species and abundance. The only one genus of Dinophyceae was Pyrocystis sp. The rareness of Dinophyceae in nature might due to this class form a cyst in a resting stage, and the cyst then settles on the seabed and rests until environmental conditions support it again (Fathurrahman and Aunurohim 2014)

The abundance of phytoplankton in the Donan River Estuary was highest in December and lowest in August. There were between 17-21 genera of phytoplankton during the six months of observation. The abundance of phytoplankton $>12500$ cells $/ \mathrm{m}^{3}$ belongs to the high category (Haninuna et al. 2015), thus the abundance of phytoplankton in the Donan River Estuary was considered high. The highest abundance of phytoplankton in Station 5 was probably due to this station was closest to the sea water in which the environmental conditions could be more stable than in other stations.

The structure of phytoplankton community is determined by the diversity of phytoplankton types and by environmental factors, such as the intensity of light and nutrients (Boney in Wulandari 2011). The index value of diversity, evenness, and dominance can be used to judge the stability of the phytoplankton community in the ocean (Duarte et al. 2012). Our results showed that the diversity indices ranged 2,04 to 2,32. According to Yuliana et al. (2012), the index value of diversity $1<\mathrm{H}^{\prime}<3$ described a moderate level of diversity with medium ecological stress. According to Basmi (2000), the condition of moderate community is a condition which can readily change even though the change of its environment is not relatively significant.

The evenness is the description of how big is the spread of similarity of the number of individuals at the community level (Odum 1971). The evenness index value (E) temporarily ranged from 0.81 to 0.88 , and especially was between 0.81 and 0.88 . This indicated that the spread of each phytoplankton taxon tended to be equal (Dash 2001).

The dominance index is used to determine whether there is a single species dominating a community. According to Dash (2001), the dominance index ranges between value of 0 and 1 . If the index value is close to 0 , it means that there is be no species dominating. On the other hand, if $\mathrm{E}$ value is close to 1, it means that at least there was one species dominating. The index value of dominance (D) showed that there were no species of phytoplankton dominating.

The station grouping obtained shows there are as many as. The habitat grouping was made based on the phytoplankton abundance and 3 zones resulted from the grouping. Station 1 and 2 had $88.21 \%$ similarity index and between station 3 and 4 the similarity index was $76.90 \%$, while Station 5 was not similar to any other stations. Zone 1 comprised of Station 1 and 2, zone 2 was formed from Station 5 . Station 5 did not have any similarity with any other stations because this station is located close to the ocean. Therefore, this station showed very diverse phytoplankton. Zone 3 was formed from Station 3 and 4. Station 3 and 4 located in the same water body, i.e., estuary, and had similar phytoplankton abundance.

Physical-chemical parameters in the estuary water of Donan River were not spacially and temporarily different significantly. The result of the measurement of water quality parameters is still normal to support the life of phytoplankton. The water temperature (in average) 
obtained temporarily ranges from $27.04-31.32^{\circ} \mathrm{C}$. The value of temperature obtained is different significantly. According to Widyarini (2016), the range of temperature is not very different because the level of ultraviolet radiation is relatively the same. The range of temperature obtained is still appropriate to the life of phytoplankton. Effendi (2003) stated that the water temperature is influenced by the season, altitude, the height of sea level, time in a day, wind circulation, cloud cover, and the depth of water. Temperature can be influenced by the existence of phytoplankton. The range of temperature which is optimal for the growth of phytoplankton $20-30^{\circ} \mathrm{C}$.

The value of salinity in a coastal river is influenced by the fresh water from rivers (Effendi 2003). Salinity of the water in Donan River estuary varied between monthly periods, 26.60-35.40\% \%, as well as among sampling stations, however, they were not significantly different based on the measurement temporarily. According to Dahuri et al. (1996), salinity is one of the parameters which determines the types of phytoplankton found in an ocean, which it self-depends on the characteristics of the phytoplankton. The value of salinity obtained is very high, but this is still good for the growth of phytoplankton. Nontji (2008), stated that salinity of $11-40 \%$ is the range of salinity which is appropriate to the life of phytoplankton. Some physicochemical parameters, i.e., TSS, pH, DO, Nitrite, Nitrate, Ammonia, and Phosphate are still suitable for biota to live in the Segara Anakan Lagoon.

The result of the analysis, biplot of the main component showed that in zone 1, the Class Chlorophyceae tended to be close to water temperature, nitrate, and nitrite. The value of correlation between phytoplankton and the water quality indicates that the parameter of nitrate has a very powerful effect, so this could affect the abundance of phytoplankton, while the temperature correlated weakly to the abundance of phytoplankton. The Class Bacillariophyceae in zone 2 tended to close be to influence by salinity, depth, transparency, and orthophosphate. The value of correlation between phytoplankton and the water quality described that the salinity and the depth parameters correlated strongly. Furthermore, the transparency also correlated quite strongly, while the parameter of orthophosphate correlated weakly towards the phytoplankton. Zone 3 described that the Class Dynophyceae tended to be close to ammonium and DO. The correlation value of phytoplankton with the DO described a strong correlation. The closeness between water quality parameters and certain phytoplankton class explained that not all water quality parameter based on the zone only influenced one type of phytoplankton. However, all parameters also influenced other types of phytoplankton.

The distribution and abundance of phytoplankton are strongly influenced by the aquatic environment (Soedibjo 2006). The correlation result shows that there is a significant correlation between environment parameter and phytoplankton at level $95 \%(0.05)$. The main parameters that influence the abundance of phytoplankton in the study sites are transparency, salinity, DO, and nitrate. The correlation values obtained were transparency (0.41), salinity (0.74), DO (0.76), and nitrate (0.82). According to
Damar (2014), the primary productivity of phytoplankton depends on the availability of nutrients and light, but light is not a limiting factor in the development of phytoplankton in tropical waters. Plankton and chemical parameters i.e., salinity and $\mathrm{pH}$ had a positive correlation (Widyarini et al. 2017). Chrismadha and Ali (2007), found that there was a strong correlation between the phytoplankton community and turbidity, $\mathrm{pH}$, dissolved oxygen, total dissolved solids, and phosphates. A study conducted by Radiarta (2013) in the Alas Strait showed that environmental parameters which had significant correlation to phytoplankton were temperature, brightness, nitrate, and phosphate.

In conclusion, phytoplankton in the estuary waters of the Donan River consisted of three classes, namely Bacillariophyceae (17 genera), Chlorophyceae (4 genera), and Dinophyceae (1 genus ). Bacillariophyceae consists of Biddulphia sp., Chaetoceros sp., Cocconeis sp., Coscinodiscus sp., Cyclotella sp., Denticula sp., Dytilum sp., Eucampia sp., Gyrosigma sp., Hemialus sp., Hyalodiscus sp., Melosira sp., Navicula sp., Nitzchia sp., Pleurosigma sp., Thalassionema sp., and Thalassiotrix sp., Chlorophyceae consist of Closterium sp., Cosmarium sp., Staurastrum sp., Volvox sp., The Class Dinophyceae found was Pyrocystis sp. The diversity of phytoplankton in the Estuary of Donan River was categorized into moderate with the medium ecological pressure indicating an aquatic moderately ecological stressed. The habitat grouping based on the abundance of phytoplankton had formed three zones of habitat, i.e., zone 1 (Station 1 and 2), zone 2 (Station 5), and zone 3 (Station 3 and 4). Nitrate, nitrite, temperature, salinity, depth, transparency, and orthophosphate are marine parameters affecting the structure of phytoplankton in the estuary of the Donan River.

\section{REFERENCES}

Abida IW. 2012. Community structure and abundance of phytoplankton in estuary waters of Porong River Sidoarjo. J Kelautan 3 (1): 1-5. [Indonesian]

APHA. 2012. Standard Methods for the Examination of Water and Wastewater. 21 st ed. American Public Health Association, Ohio, US.

Ardli ER. 2008. A tropic flow model of the Segara Anakan Lagoon, Cilacap, Indonesia [Dissertation]. University of Bremen, Bremen, DE.

Basmi J. 2000. Planktonology: Plankton as Bio-indicator of Water Quality. Faculty of Fisheries and Marine Sciences, Bogor Agricultural University, Bogor. [Indonesian]

Bazin P, Jouenne F, Friedl T, Deton-Cabanillas A-F, Le Roy B, Véron B. 2014. Phytoplankton diversity and community composition along the estuarine gradient of a temperate macrotidal ecosystem: combined morphological and molecular approaches. PLoS ONE 9 (4): e94110. DOI: 10.1371 /journal.pone.0094110

Brogueira MJ, Maria RO, Graca C. 2007. Phytoplankton Community structure defined by key environmental variables in Tagus estuary, Portugal. Science Direct 64: 616-628.

Cahyani LE. 2001. The physical, chemical, and biological qualities of the Donan River waters around the holding basin of Pertamina oil processing industry Cilacap, Central Java [Thesis]. Bogor Agricultural University. Bogor. [Indonesian]

Chrismadha T and Ali F. 2007. The dynamics of the phytoplankton community in a pool of closed-flow system with rapid flowing. $J$ Oceanography and Limnology in Indonesia. 3: 325-338

Dahuri RJ, Rais SP, Ginting, Sitepu MJ. 1996. Integrated Resource Management in Coastal and Marine Areas. PT. Pradnya Paramita, Jakarta. [Indonesian] 
Damar A. 2003. Effect of enrichment on nutrient dynamics, phytoplankton dynamics and productivity in Indonesia's tropical water: a comparison between Jakarta Bay, Lampung Bay and Semangka Bay. [Dissertation]. Christian Albrechts Universitat, Kiel, DE.

Damar A, Colijn F, Hesse KJ, Wardiatno Y. 2012. The eutrophication of Jakarta, Lampung and Semangka Bays: nutrient and phytoplankton dynamics in Indonesian tropical water. J Trop Biol Conserv 9 (1): 61 81. $\square$

Damar A, Colijn F, Hesse KJ. 2014. Effect of different nutrient loadings on planktonic primary production in embayments of Indonesia. J Trop Biol Conserv 11: 63-85 $\square$

Dash MC. 2001. Fundamentals of Ecology 2nd ed. Tata McGraw-Hill, New Delhi.

Duarte CM, Agusti S, Gasol JM, Vaque D, Vazques DE. 2000. Effect of nutrient supply on the biomass structure of planktonic communities: an experimental test on a Mediterranean coastal community. Mar Ecol Prog Ser 206: 87-95.

Effendi H. 2003. Water Quality Review: For Resource Management and Water Environment. Kanisius, Yogyakarta. [Indonesian]

Fathurrahman, Aunurohim. 2014. Study of the composition of phytoplankton and its relation to the location of pearl shell cultivation (Pinctada maxima) in Sekotong Waters, West Nusa Tenggara. J Pomits Technique 3 (2): 1-6.

Gao X, Song J. 2005. Phytoplankton distribution and their relationship with the environment in the Changjiang Estuary, China. Mar Poll Bull 50: $327-335$

Haninuna EDN, Gimin R, Kaho LMR. 2015. Utilization of phytoplankton as bio-indicator of various types of pollutants in intertidal waters of Kupang City. J Ilmu Kelautan 13 (2): 72-85

Isnaini. 2011. Structure of the phytoplankton community in the waters of the Banyuasin river estuary, Banyuasin regency, South Sumatra. Maspari J 9 (2): 56-68

Nastiti AS, Hartati ST. 2013. Structure of plankton community and water environment conditions in Jakarta Bay. J Bawal. 5 (3): 131-150. [Indonesian]

Nontji A. 2008. Sea Plankton. LIPI Press, Jakarta. [Indonesian]

Odum EP. 1971. Fundamentals of Ecology, 3rd ed. W.B. Saunders Co. Philadelphia
Partuti T. 2014. Effectiveness of cation exchange resins to reduce Total Dissolved Solids (TDS) levels in wastewater produced by oil and gas industry. Process Integration. 5 (1): 1-7. [Indonesian]

Radiarta IN. 2013. The relationship between distribution of phytoplankton and water quality in Alas Strait, Sumbawa Regency, West Nusa Tenggara. J Bumi Lestari. 12 (2): 234-243.

Ramadhania S, Maresi P, Priyanti, Yunita E. 2015. Phytoplankton as bioindicator of saprobes waters at Situ Bulakan, City of Tangerang. J Biologi 8 (2): 1-10. [Indonesian]

Robinson D. 2010. Oil and gas: water treatment in oil and gas production does it matter?. Filtration \& Separation. 47 (1): 14-18.

Siregar A. 2006. Spatial analysis of the phytoplankton community structure in the waters of Hurun Bay, Lampung. [Hon. Thesis]. Bogor Agricultural University. Bogor. [Indonesian]

Soedibjo BS. 2006. The structure of the phytoplankton community and its relationship with several environmental parameters in the waters of Jakarta Bay. J Oceanography and Limnology in Indonesia. 40: 65-78. [Indonesian]

Sudaryanto A. 2001. Macrozoobenthos community structure and chemical physiological conditions of sediment in Donan Waters. J Environ Technol 2 (2): 119-123. [Indonesian]

Widyarini H. 2016. Plankton community structure in estuary waters of Majakerta River, Indramayu. [Hon. Thesis]. Bogor Agricultural University. Bogor. [Indonesian]

Widyarini H, Pratiwi NTM, Sulistiono. 2017. Zooplankton community structure at Majakerta Estuary and its surrounding waters, Indramayu regency, West Java. Jurnal Ilmu dan Teknologi Kelautan Tropis 9 (1): 91-103.

Wulandari DY. 2011. Spatial distribution of phytoplankton in the waters of the Bali Strait [Thesis]. Bogor Agricultural University, Bogor. [Indonesian]

Wulandari DY. 2015. Structure of the phytoplankton community and the level of fertility of the coastal waters of Tangerang [Thesis]. Bogor Agricultural University, Bogor. [Indonesian]

Yamaji I. 1970. Illustrations of the Marine Plankton of Japan. Hoikusha, Japan.

Yuliana, Adiwilaga EM, Harris E, Pratiwi NTM. 2012. The relationship between phytoplankton abundance and physicochemical parameters of the waters in Jakarta Bay. J Akuatika 3 (2): 169-179. [Indonesian] 